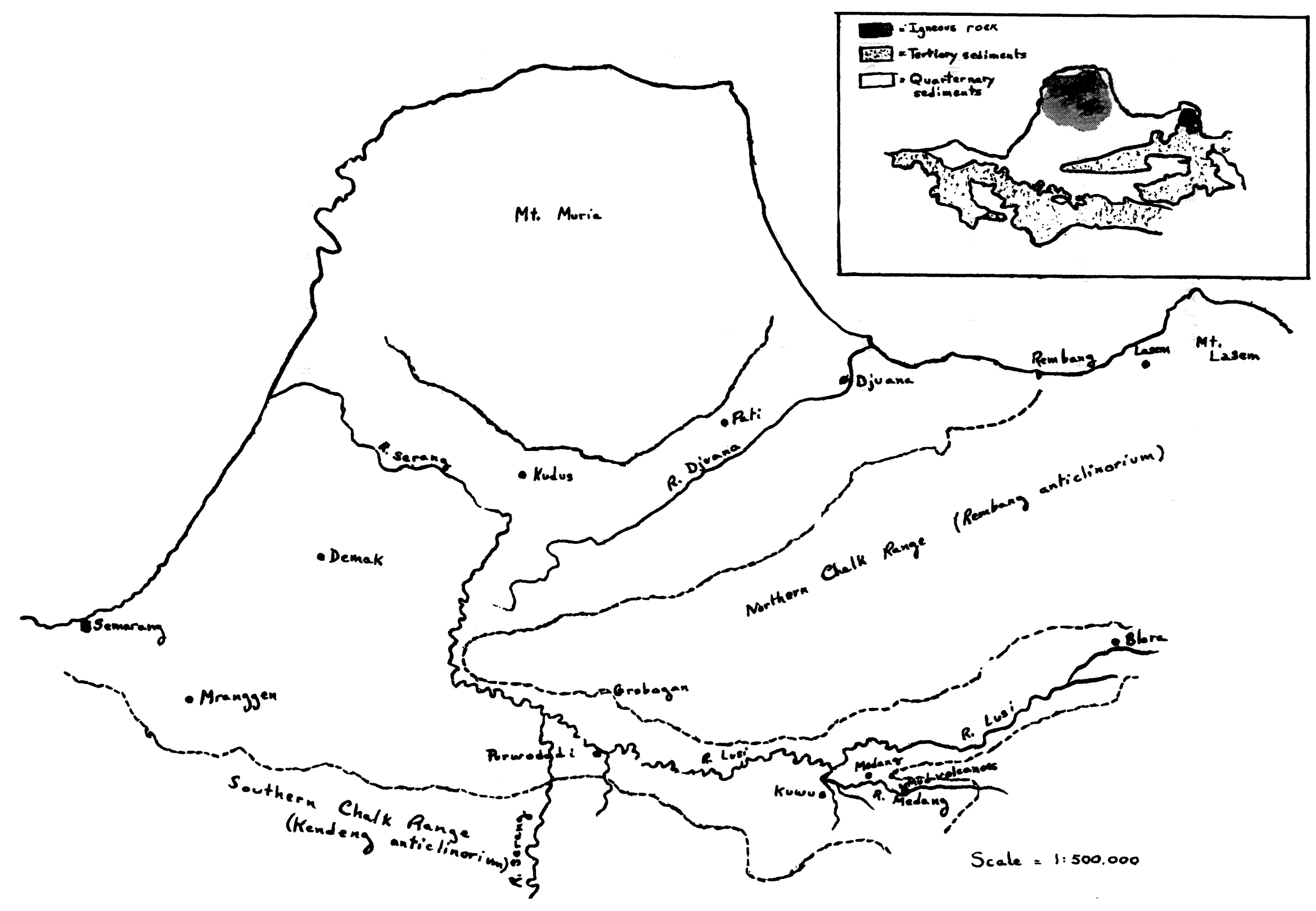




\title{
A GEOGRAPHICAL RECONSTRUCTION OF NORTHEASTERN CENTRAI JAVA AND THE LOCATION OF MEDANG
}

\author{
R. Soekmono
}

Of the Indonesian kingdoms which flourished before the coming of Islam (say before 1500 A.D.) only the last, Madjapahit, has left the remains of its capital city. No traces are left of the chief cities of the earlier kingdoms; Singhasari and Kadiri still preserve their names in the present towns of Singosari and Kediri, but there is no certainty that the latter were founded on the ruins of their capitals. Several inscriptions give the names of capital cities, but the epigraphic material fails to provide a clue as to their location. Toponymic surmises have been made, sometimes quite satisfactorily; but they have also yielded two or more possible locations and so have complicated matters further. This is precisely the problem with Medang, since its name is preserved in several places in both southern and northern Central Java.

The primary focal region of Indonesian history from the eighth to the tenth centuries was Central Java, and Medang was the capital of its principal kingdom. Now it happens that the southern part of Central Java provides historical documentation in the form of an accumulation of architectural monuments ( $t j a n d i)$ while the northern part is very poor in archaeological remains. It is therefore only natural that archaeologists and historians have sought to locate Medang in the south. 1 on the other hand, the folk memory of a "Kingdom of Mendang Kemulan," handed down to the present day through legends and stories, has it that Mendang Kemulan was situated in the Grobogan district of northeastern Central Java. There, indeed, we find a number of villages bearing the name "Medang": Medang, Medang Ramesan, Medang Kemit, Medang Kemulan, and others. A river Medang also runs through the area.

We must, of course, treat tradition and legend with caution as historical material. Stutterheim, however, was of the opinion that a tradition as deeply rooted as that concerning the location of Mendang Kemulan must have its historical basis and that therefore the question should be investigated

1. See N. J. Krom, Hindoe-Javaansche Geschiedenis, 2nd edition ('s-Gravenhage: M. Nijhoff, 1931), PD. 167-170; and Poerbatjaraka, "Enkele oude plaatsnamen," Tijdschrift voor Indische Taal-, Land- en Volkenkunde (LXXIII), 1933, especially Pp. 516-519. 
further. Having shown that in the realms of Singhasari and Madjapahit the tjandi were always erected outside the capital cities--indeed, in most cases at a great distance from them-he asked whether the same might not also be true of the kingdoms of Central Java. His conclusion was that he was inclined to agree with the living tradition and to locate Medang in the Grobogan district. The presence of the tjandi in the south he explained by considering this area to have been the "realm of the dead" 2 (and indeed, tjandi are mausoleums). This suggestion later found support in the results of ceramological investigations in the area of the Prambanan and Sorogedug plains. Ceramics and potsherds systematically collected there in 1939 and 1940 originated from the same period as the monuments but, including no household articles, did not indicate the presence of dwelings. 3

The results of this investigation made stutterheim anxious to know what the ceramic remains of the archaeologically poor Grobogan district would reveal, and a systematic exploration of that area was begun by De Flines in mid-1940. Its aim was not especially to locate Medang but rather to gain an insight into the spread and density of ceramic remains so as to be able to draw conclusions regarding former major settlement and administrative sites, trading centers, and traffic routes in northeastern Central Java. ${ }^{4}$ However, Stutterheim's suggestion as to Medang's location was taken into account by devoting particular attention to the discovery of material from the tenth century and earlier. The Japanese invasion of Java in the beginning of 1942 unfortunately brought an abrupt end to the investigation, leaving the Semarang and Demak regions unexplored. Even so the results were remarkable, especially insofar as they concerned the dating and distribution of the ceramic finds.

The ceramics found in the explored regions can be divided into two groups: those originating from the eighth to the tenth centuries and those from more recent times. The older ceramics were all found in the hilly regions and their environs, while the more recent ones were located in the river valleys and alluvial plains. Some parts of the latter, in fact, yielded no ceramics older than the eighteenth century.

2. W. F. Stutterheim, "Oudheidkundige aanteekeningen," Bijdragen tot de Taal-, Land, en Volkenkunde van Nederlandsch-Indie (IXXXIX), 1932, pp. 278-282.

3. Oudheidkundig Verslag, 1939, p. 14 ; and 1940, pp. 24-25.

4. A complete report is published in E. W. van Orsoy de Flines, "Onderzoek naar en van keramische scherven in de boden in Noordelijk Midden-Java, 1940-142," Oudheidkundig Verslag 1941-1947 (Bandoeng: Nix, 1949), pp. 66-84. 
This circumstance led De Flines to inquire why these areas seemed not to have been inhabited before 1700, a puzzle he left to the geographers and historians. ${ }^{5}$

In 1957 I presented a paper to the ninth Pacific Science Congress in Bangkok which attempted to locate Sriwidjaya on the basis of a geomorphological reconstruction of Sumatra's eastern coastline. 6 The results of this endeavor have so far not been spectacular, but it seems to me they have shown that by taking into account past geographical configurations new horizons may be opened for the location and reconstruction of historical sites. We find, for example, that the remarkable distribution of older and more recent ceramics in the area explored by De Flines agrees with the geomorphological formations of that region.

According to $\operatorname{Van}$ Bemmelen, 7 the stretch of alluvial plain between Semarang and Rembang is a downwarp which has the character of a broad synclinal basin between the westward plunging end of the Rembang anticlinorium on the one side and the Muriah complex on the other. This downwarp already existed in the Neogene (late Tertiary) period and was transformed into a strait by the eustatic rise of the sea level in the later Quaternary. As the southern border of the alluvial plain is actually the Kendeng anticlinorium, the westward plunging end of the Rembang hills can be considered as a promontory. A map constructed with this configuration would show the Muriah volcano as an island off the north coast of Central Java, with the Semarang-Rembang shore line running to its south--instead of encompassing it as it does today--and opening up a gulf penetrating as far east as the upper course of the Lusi river. The two largest rivers of the area would have emptied into this gulf, and it was apparently there that a silting process began which eventually led to the filling in of the SemarangRembang strait. The silting up of the waterway took some time to accomplish, and according to Niermeyer ${ }^{8}$ in the

5. Ibid., p. 75 .

6. Soekmono, "Early Civilizations of Southeast Asia," Journal of the Siam Society (XLVI, 1), June 1958, PP. 17-20. The material was presented in more detailed and developed form to the First National Scientific Congress in Malang, 1958, and was later published as "Geomorphology and the Location of Çriwijaya," Madjallah Ilmu-ilmu Sastra Indonesia (I, I), April 1963, pp. 78-90.

7. R. W. van Bemmelen, The Geology of Indonesia (The Hague: Government Printing Office, 1949), I, Pp. 592-593.

8. J. F. Niermeyer, "Aardrijkskundig overzicht," in $\mathrm{H}$. Colijn (ed.), Neerlands Indië (Amsterdam: Elsevier, 1911), I, p. 41. 
eighteenth century it was still possible for seagoing vessels to pass through the strait from Demak via Kudus and Pati to Rembang. This, it would seem, is the answer to De Flines' question as to why the area appeared to have been uninhabited at an earlier period.

The process by which alluvium was deposited in the Semarang-Rembang strait should be subjected to further investigation in view of the fact that at the beginning of the sixteenth century Demak, originally located on a site well within the strait, had become a major seaport and the capital of the first Islamic kingdom in Java, while Kudus, also situated in a formerly inundated area, soon followed it as a center of Islamic activity. It is therefore doubly a pity that De Flines was not able to investigate the ceramic remains of the Demak region.

Whatever the process of sedimentation in the SemarangRembang area and its effect on the development of historical centers during the second millenium, we may assume that the period prior to the tenth century saw the Muriah as an island separated from Java by a strait stretching from Semarang eastward to Rembang. By linking up the places where the older ceramics are found, we can define the coastline more precisely, discovering it to have run along the hilly regions from Semarang 9 eastward to Purwodadi, where it formed a gulf, and then turning around the promontory of the Northern Chalk Range and proceeding east to Rembang. This coastline proves to run along the 25-meter contour line on a present-day topographic map. It would seem, therefore, that the areas between Semarang and Rembang which now lie lower than 25 meters above sea level were once part of the strait.

In this configuration we find that the Medang region was an area situated on the gulf of Purwodadi, a favorable location for the capital of a state. Indeed when, ten years after his original exploration, De Flines resumed his study of the ceramic remains of northeast Central Java and applied his findings to the location of various historical sites, 10 he concluded of the Medang Ramesan district that "there is

9. The Semarang-Ungaran region seems to have been explored, perhaps on another occasion, but no reports on the investigation are available. However, the findspots of the older ceramics indicated on the map drawn by De Flines show that in the Semarang area they were situated above the 25-meter contour line.

10. E. W. van Orsoy de Flines, "Hasin-Medang-Kuwu Lang-pi-ya," Tijdschrift voor Indische Taal-, Land- en Volkenkunde (LXXXIII, 4), 1949, PP. 424-429. 
an excellent chance that the palace of Medang had stood on that spot and that there is truth in the popular tradition, which is still preserved very strongly there."li In the light of the geomorphological development we have described, it seems safe to say the "excellent chance" is a certainty.

To buttress this conclusion we can refer to historical clues as to Medang's location. Toward the western border of the Medang region there is a place called Kuwu, which is known for its mud volcanoes. The mud is brackish, and since time immemorial the population has made its salt from the salt wells it forms. These salt wells were known to the Chinese of the T'ang period and were mentioned in their dynastic records, which in dealing with Kaling or Java inform us that "there is a cavern from which salt water bubbles up spontaneously."12 As there are no similar salt wells anywhere else in Indonesia, it seems certain that we can identify this "cavern" with the salt wells of Kuwu.

The same records inform us that the king frequently went to Lang-pi-ya in the mountains in order to gaze on the sea. The word "frequently" implies that Lang-pi-ya must have been not far distant from Medang, and De Flines has plausibly located it on the eastern slopes of Mount Lasem.13 This location fits very well indeed with our reconstructed geographical configuration. The Chinese records further report that "the people make fortifications of wood and even the largest houses are covered with palm leaves."14 This, it would seem, is the reason why not much is left in the way of material evidence of Medang, and why the area is archaeologically so poor compared to the "realms of the dead" in southern Central Java. (Another fact which might explain the archaeological poverty of the area is that it yields only limestone of insufficient durability for construction purposes.)

I should point out that by placing Medang in the Grobogan district we have by no means solved all the problems connected with pinpointing its precise location in the eighth to the tenth centuries. Inscriptions record the

11. Ibid., p. 426 .

12. W. P. Groeneveldt, "Notes on the Malay Archipelago and Malacca, Compiled from Chinese Sources," Verhandelingen van het Bataviaasch Genootschap van Kunsten en Wetenschappen (XXXIX, 1), 1876, P. 13.

13. De Flines, "Hasin-Medang-Kuwu Lang-pi-ya," pp. 427-429.

14. Groeneveldt, op. cit., p. 13. 
existence then of a "ri mamratipurastha madaang,"15 a "ri mọang.ri pob pitu," 16 a "mdang i bhümi mataram," 17 and " $i$ mdang $i$ bhümi mataräm i watu galuh,"lig so that we must ask whether these Medangs are one and the same or whether the various predicates distinguish between separate localities. My purpose has not, however, been to solve the problem of Medang completely but to demonstrate the need for those who attempt to reconstruct the history of an area to ascertain its geographic features during the period under investigation.

15. De Casparis, Prasasti Indonesia (Bandung: Masa Baru, 1956), II, PP. 280-330 (Çiwagṛha inscription, 778 Ç.), especially p. 312 .

16. W. F. Stutterheim, "Een belangrijke oorkonde uit de Kedoe," Tijdschrift voor Indische Taal-, Land- en Volkenkunde (LXVII), 1927, PP. 173-215, especially p. 210 (Mantyasih inscription, 829 Ç.).

17. J. L. A. Brandes, "Oud-Javaansche Oorkonden" (ed. N. J. Krom), Verhandelingen van het Bataviaasch Genootschap van Kunsten en Wetenschappen (LX), 1877, p. 88 (Añjuk Laḍang inscription, 859 C.).

18. Ibid., p. 100 (Paraḍah inscription, 865 ç.). 